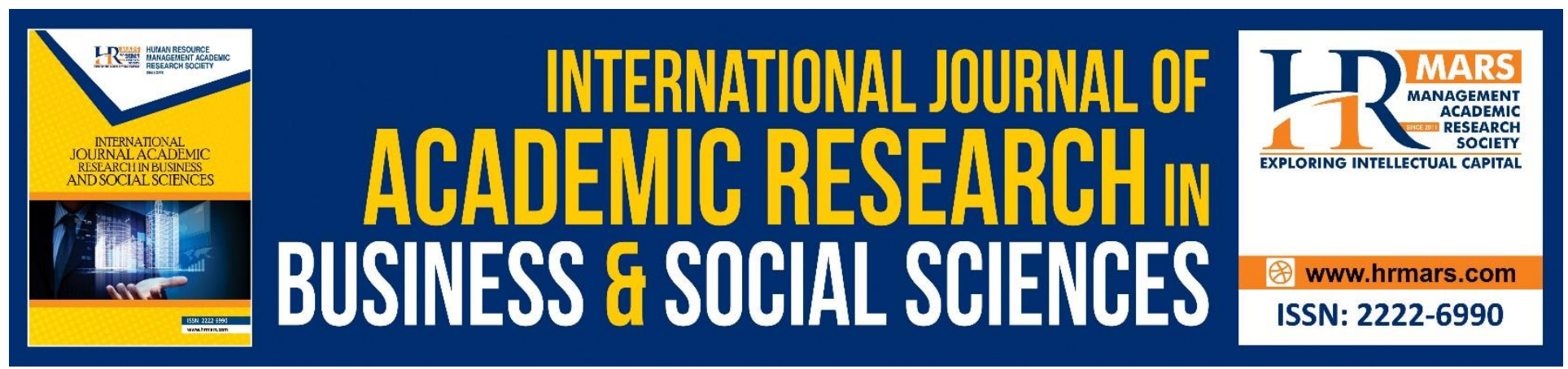

\title{
Malaysian Healthcare Sector: Service Quality and Patient Performance
}

\section{Maria Shazwina Tajudin, Nurul Fadly Habidin}

To Link this Article: http://dx.doi.org/10.6007/IJARBSS/v10-i7/7607

DOI:10.6007/IJARBSS/v10-i7/7607

Received: 02 May 2020, Revised: 03 June 2020, Accepted: 10 July 2020

Published Online: 27 July 2020

In-Text Citation: (Tajudin \& Habidin, 2020)

To Cite this Article: Tajudin, M. S., \& Habidin, N. F. (2020). Malaysian Healthcare Sector: Service Quality and Patient Performance. International Journal of Academic Research in Business and Social Sciences, 10(7), 776782.

Copyright: @ 2020 The Author(s)

Published by Human Resource Management Academic Research Society (www.hrmars.com)

This article is published under the Creative Commons Attribution (CC BY 4.0) license. Anyone may reproduce, distribute, translate and create derivative works of this article (for both commercial and non-commercial purposes), subject to full attribution to the original publication and authors. The full terms of this license may be seen

at: http://creativecommons.org/licences/by/4.0/legalcode

Vol. 10, No. 7, 2020, Pg. 776 - 782

http://hrmars.com/index.php/pages/detail/IJARBSS

JOURNAL HOMEPAGE

Full Terms \& Conditions of access and use can be found at http://hrmars.com/index.php/pages/detail/publication-ethics 


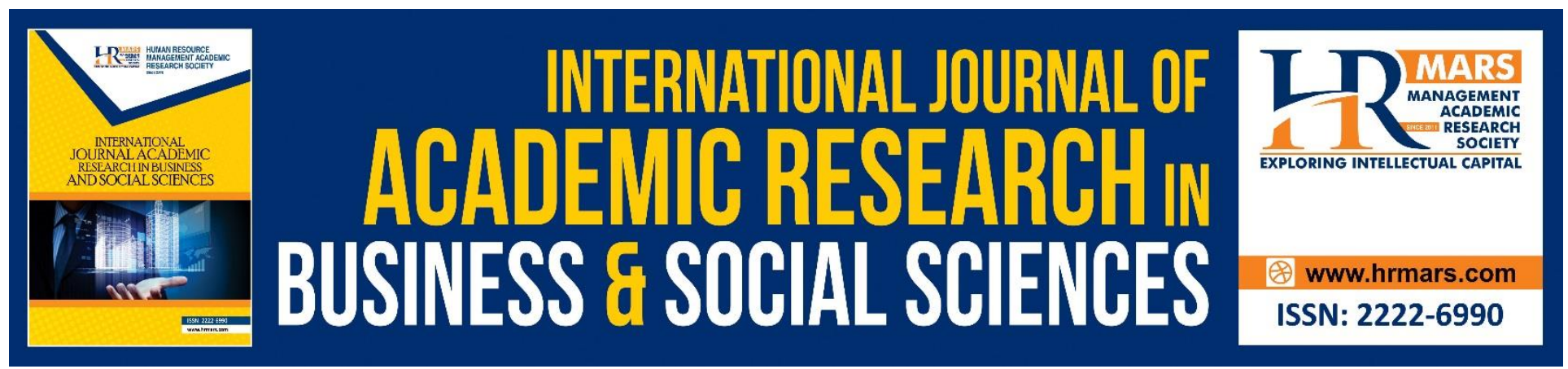

\title{
Malaysian Healthcare Sector: Service Quality and Patient Performance
}

\author{
Maria Shazwina Tajudin, Nurul Fadly Habidin \\ Faculty of Management and Economics, Sultan Idris Education University, 35900 Tanjung Malim, \\ Perak, Malaysia.
}

\begin{abstract}
Healthcare are often in particularly characterized in interacting the variety of wide in activities to provide the great quality while deliver the services. By adapting the technique for improvement in a business philosophy were lead for being the epitome of services. More recently the advantages increasing the service quality approach have become more acceptance in the organization process. Hence, the purpose of this study to determine the relationshio between service quality and patient performance in Malaysian healthcare sector. A structured technique has been used by Structural Equation Modeling (SEM - PLS).
\end{abstract}

Keywords: Healthcare, Service Quality, Patient Performance.

\section{Introduction}

Service quality is a description of customer expectations and perception with the services provided. The healthcare system of Malaysia sector is in its capabilities to serve the best quality in the services. Therefore, the quality in services are the main objective to determinant in patient performance. It is a technical measured that related with the organization performance. To design and deliver the great quality of services pertaining both perception and expectations in order to have a bearing on performance.

The services attempt priority in care for health which affects and related with the process in the organization. Enhance, there has been changed in standard of lifestyle and demanding in living environment causes interest in healthcare service. About 15 years ago, mostly previous study determined that it is an extremely grown on the service quality. An effort to improve the performance effectively, services in healthcare around the world especially in Malaysia need adopted a techniques that can implement the process.

\section{Literature Review}

Healthcare Sector

It is like a vital when the importance of healthcare often attention in the economics scale (Khalil et al., 2016). As the world's healthcare have relocated to increasing in providing the great quality in 
services especially in hospitals. Therefore, throughout the world an ageing costly and population have pressures the healthcare over the past decade (Shafei et al., 2015). Simultaneous with the changes in healthcare sector, it is often to improve and maintaining the performance (Van et al., 2013). Enhancing in both efficiency and effectively is a great solution which is able and suitable in managerial healthcare (Crema \& Verbano, 2016). Thus, despite a global in healthcare especially in government hospitals or called as public hospitals lead the implementation in service quality (Hussain \& Malik, 2016).

\section{Service Quality}

The quality services become the main speculation issues that being the top affected in our lives. Mostly the higher in the service quality especially in hospitals is accessibility upon the location and income (Shradha et al., 2018). All the people still struggle to find the best services which can satisfy themselves including the needed in their lives. There are about five terms of service quality had founded and implemented by the Parasuraman et al., (1988) such as Tangibility (TN), Reliability (RE), Responsiveness (RS), Assurance (AS) and Empathy (EM). To evaluate the service outcome is based on these five dimensions according by Parasuraman et al. (1985):

a. Tangible (TN) is one of the physical equipment, tools and facilities that useful for staff appearance and provide services.

b. Reliability (RE) concerns the ability to accurate the customer and provide the service dependably which is consists for dependability and consistency.

c. Responsiveness (RS) refers to offer a prompt service based on the readiness and willingness.

d. Assurance (AS) involves the ability to attract the confidence level and trust among staffs knowledge because it is one of the necessary skills and knowledge that can be using for providing the best service to their customers.

e. Empathy (EM) concerns about the customers' needs especially in term of their demanding, understanding their main requirements and caring about their behaviour of buying.

Expectations in tangible quality must be showed in environment especially in side of hospital's foods (Mosadeghrad, 2013). What we know about service quality is largely based on empirical studies that investigate in public hospitals indicate perceived services better in terms of public sector (Asma et al., 2017). Previous research has indicated that mostly employees' tangibles, nursing tangibles and hospital premises have a positive impact on service quality (Shafei et al., 2015). A recent study by Laureani et al. (2017), the main important for healthcare industry is focus on the positive impact in the quality of life among patients.

To develop the service quality, several management departments in organization supposedly need to adapt some tools such as lean that have been tested by healthcare industry (Cavallone et al., 2017). By the service quality, could lead the patient satisfaction (Aradhana et al, 2012).

\section{Patient Performance}

Correspondingly, focusing on reducing the problems which related with the deliver of services is one of the business strategies to lead excellence in performance (Bhat et al., 2014). As mentioned by Deblois \& Lepanto, 2016), an improvement has been growing efficiently in healthcare performance during 15 years ago. Increasing in service quality also has been adopted to the healthcare sector 
INTERNATIONAL JOURNAL OF ACADEMIC RESEARCH IN BUSINESS AND SOCIAL SCIENCES

Vol. 10, No. 7, July, 2020, E-ISSN: 2222-6990 @ 2020 HRMARS

through implemented in performance processes (Cheng et al., 2015). As an example, it is new concept in healthcare sector of Finland which regarding on the growing in the work environment which affected in their daily performance (Hihnala et al., 2018). Quality in service can be defined at achieving the aims in effectively which interaction between performance and operational (Papadopoulos, 2011). By adopting a techniques that can decrease and implement the services rapidly resulting in acute the business tiday (Sharma et al., 2016).

\section{Research Hypotheses}

Furthermore, it is a platform to the healthcare industry for providing the best quality and services which can increase the customer satisfaction and implement the organisational performance (Mosadeghrad, 2014). ). Refer from Rama Krishna et al., (2016) the findings in the study showed the positive significant between the healthcare service quality and patient satisfaction. . Overall in service hospital Naik et al. (2013) studied that has a connecting between the services provided by the hospital and patient satisfaction.

Researchers are beginning to link service quality which is including the factor of process in organizational and patient value positive related with the performance (Hadid \& Mansouri, 2014). Thus, it become contribution within the performance and implementation the quality. In doing so, technically the productivity in performance were have significant relation with the process of service (Hadid et al., 2016).

$\mathrm{H1}$ : The service quality has significant relationship on patient performance.

\section{Research Methodology}

The research methodology is for the successful developing in the framework between service quality and patient performance. In this study looked further into how service quality is applied in Malaysian healthcare sector in terms of patient performance. In addition, the purpose of study is to determine the relationship between service quality and patient performance. A quantitative approach was taken and the questionnaire will design to collect the data once distribute the questionnaire in public hospitals. To ensure the construct of items in questionnaire are relevancy and accurate, the final draft of questionnaire will be sent to the persons who were experts in healthcare sector.

In addition, the descriptive statistics and preliminary data including the means, standard deviation and frequencies will analyze using the statistical package for the social sciences (SPSS) version 26. Furthermore, this study also will using the structural equation model (SEM - PLS) technique to perform the data of feedback from the respondents in public hospitals and test the measurement model.

\section{A Proposed Research Model}

Based on the literature review, the service quality has related with the patient performance. It showed that the influences of service quality and patient performance would be appropriate for the healthcare sector. Therefore, the purpose of this study is to determine the relationship between service quality and patient performance. A proposed research model as follows. 


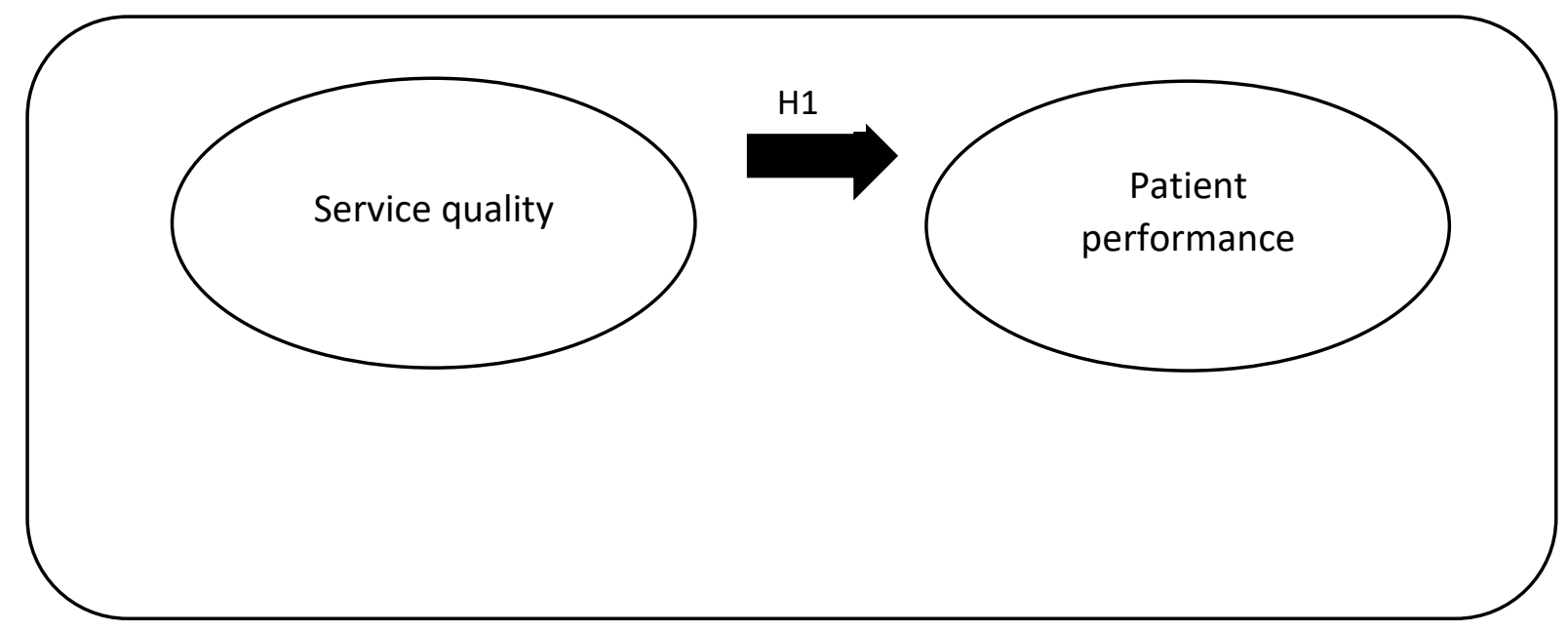

\section{Conclusion and Future Research}

Malaysian healthcare sector is one of the complex business which is must continuously balance the needed among patient together with the quality in services. The philosophy of service quality such as tangibility, reliability, responsiveness, assurance and empathy have a stable role in assisting the high quality in healthcare. The previous study has shown that the service quality in healthcare sector had a great influence on the patient performance. Surely, service quality can make a significant contribution to patient performance in public hospitals.

As expected with the hypotheses that the patient performance were affected by the service quality. Many researchers have assumed that providing the great quality in services can increase the patient satisfaction. For the future research, will distribute the questionnaire to the public hospitals which is focus on the staffs as the respondents in this study. This of course the opportunities to expand the study would be deployed and sustainable.

\section{Acknowledgement}

The researcher would like to acknowledge the main supervisor Dr Nurul Fadly Habidin, UPSI and express their thanks to ERA referees for their suggestion to develop this paper.

\section{Corresponding Author}

Maria Shazwina Binti Tajudin

Department Management and Economics, University Pendidikan Sultan Idris

35600 Tanjung Malim, Perak, Malaysia 
INTERNATIONAL JOURNAL OF ACADEMIC RESEARCH IN BUSINESS AND SOCIAL SCIENCES

Vol. 10, No. 7, July, 2020, E-ISSN: 2222-6990 @ 2020 HRMARS

\section{References}

Al-Hyari, K., Abu Hammour, S., Abu Zaid, M. K. S., \& Haffar, M. (2016). The impact of Lean bundles on hospital performance: does size matter? International Journal of Health Care Quality Assurance, 29(8), 877-894. https://doi.org/10.1108/IJHCQA-07-2015-0083

Bhargava, A., Thakur, A., Mishra, B., Taneja, J., Dogra, V., Loomba, P. (2012). Patient satisfaction survey of microbiological tests done in G.B. Pant Hospital. International Journal of Health Care Quality Assurance, Vol. 25 Issue: 7, pp.555-564, https:// doi.org/10.1108/09526861211261163

Shabbir, A., Malik, S. A. (2016). Measuring patients' healthcare service quality perceptions, satisfaction, and loyalty in public and private sector hospitals in Pakistan. International Journal of Quality \& Reliability Management, 33:5, 538-557

Bhat, S., Gijo, E. V., \& Jnanesh, N. A. (2014). Application of Lean Six Sigma methodology in the registration process of a hospital. International Journal of Productivity and Performance Management, 63(5), 613-643. https://doi.org/10.1108/IJPPM-11-2013-0191

Cavallone, M., Magno, F., \& Zucchi, A. (2017). Improving service quality in healthcare organisations through geomarketing statistical tools. TQM Journal, 29(5), 690-704. https://doi.org/10.1108/TQM-12-2016-0104

Cheng, S. Y., Bamford, D., Papalexi, M., \& Dehe, B. (2015). Improving access to health Services Challenges in lean application. International Journal of Public Sector Management, 28(2), 121135. https://doi.org/10.1108/IJPSM-05-2014-0066

Crema, M., \& Verbano, C. (2016). Safety improvements from health lean management implementation: Evidences from three cases. International Journal of Quality and Reliability Management, 33(8), 1150-1178. https://doi.org/10.1108/IJQRM-11-2014-0179

Deblois, S., \& Lepanto, L. (2016). Lean and Six Sigma in acute care: a systematic review of reviews. International Journal of Health Care Quality Assurance, 29(2), 192-208. https://doi.org/10.1108/IJHCQA-05-2014-0058

Hadid, W., \& Mansouri, S. A. (2014). The lean-performance relationship in services: A theoretical model. International Journal of Operations and Production Management, 34(6), 750-785. https://doi.org/10.1108/IJOPM-02-2013-0080

Hihnala, S., Kettunen, L., Suhonen, M., \& Tiirinki, H. (2018). The Finnish healthcare services lean management: Health services managers' experiences in a special health care unit. Leadership in Health Services, 31(1), 17-32. https://doi.org/10.1108/LHS-03-2017-0020

Hussain, M., \& Malik, M. (2016). Prioritizing lean management practices in public and private hospitals. Journal of Health, Organisation and Management, 30(3), 457-474. https://doi.org/10.1108/JHOM-08-2014-0135

Laureani, A., Brady, M., \& Antony, J. (2013). Applications of Lean Six Sigma in an Irish hospital. Leadership in Health Services, 26(4), 322-337. https://doi.org/10.1108/LHS-01-2012-0002

Mosadeghrad, A. M. (2014). Why TQM does not work in Iranian healthcare organisations. International Journal of Health Care Quality Assurance, 27(4), 320-335. https://doi.org/10.1108/IJHCQA-11-2012-0110

Papadopoulos, T. (2011). Continuous improvement and dynamic actor associations: A study of lean thinking implementation in the UK National Health Service. Leadership in Health Services, 24(3), 207-227. https://doi.org/10.1108/17511871111151117

Parasuraman, A., Zeithaml, V.A., \& Berry,L.L. (1988). SERVQUAL :a multiple item scale for measuring perceptions of service quality. Journal of retailing , Vol. 64, Number 1, p.12. 
INTERNATIONAL JOURNAL OF ACADEMIC RESEARCH IN BUSINESS AND SOCIAL SCIENCES

Vol. 10, No. 7, July, 2020, E-ISSN: 2222-6990 @ 2020 HRMARS

Rama Krishna Naik Jandavath, \& Anand Byram, (2016) "Healthcare service quality effect on patient satisfaction and behavioural intentions in corporate hospitals in India", International Journal of Pharmaceutical and Healthcare Marketing, Vol. 10 Issue: 1, pp.48-74, https://doi.org/10.1108/ IJPHM-07-2014-0043

Shafei, I., Walburg, J. A., \& Taher, A. F. (2015). Healthcare service quality: what really matters to the female patient? International Journal of Pharmaceutical and Healthcare Marketing, 9(4), 369391. https://doi.org/10.1108/IJPHM-05-2014-0028

Shafei, I., Walburg, J. A., \& Taher, A. F. (2015). Healthcare service quality: what really matters to the female patient? International Journal of Pharmaceutical and Healthcare Marketing, 9(4), 369391. https://doi.org/10.1108/IJPHM-05-2014-0028

Sharma, V., Dixit, A. R., \& Qadri, M. A. (2016). Empirical assessment of the causal relationships among lean criteria using DEMATEL method. Benchmarking, 23(7), 1834-1859. https://doi.org/10.1108/BIJ-08-2014-0078

Gupta, S., Monica, S., Sharma, M., Vijaya, S. M., Sunder, V. M. (2016). Lean services: a systematic review. International Journal of Productivity and Performance Management, 65:8, 1025-1056.

Van Rossum, L., Aij, K. H., Simons, F. E., Van der Eng, N., \& Ten Have, W. D. (2016). Lean healthcare from a change management perspective: The role of leadership and workforce flexibility in an operating theatre. Journal of Health, Organisation and Management, 30(3), 475-493. https://doi.org/10.1108/JHOM-06-2014-0090 